\title{
RATIONALITY, IRRATIONALITY AND IRRATIONALISM IN THE ANTI-INSTITUTIONAL DEBATE IN PSYCHIATRY AROUND THE SECOND HALF OF THE 1970S IN ITALY
}

\author{
Matteo Fiorani \\ University of Rome, Tor Vergata \\ Review article - Received: 24/6/2020 Accepted: 21/8/2020
}

\begin{abstract}
The movements and protests of 1968 worldwide criticized the traditional idea of normality. From the 1970s onwards, psychiatry and antipsychiatry became an ideological battleground centered on the boundaries between normality and madness. In this scenario, characterized by a deep cultural and political transformation within the Left, the traditional concept of rationality and its very connection with irrationality was called into question. As a consequence, the very ideal of reason was questioned. This paper will explore the debate on rationality, irrationality and irrationalism within the so-called antiinstitutional psychiatry and its reception in the Italian New Left during the second half of the 1970s.
\end{abstract}

Keywords: Antipsychiatry; psychiatric reforms; New Left; Italy

\section{The Boundaries Between Reason and Madness: The Italian Case}

Psychiatry built, or at least set out to build, its scientific and professional foundations on the capacity to define the boundaries between reason and madness. Nevertheless, while trying to turn irrational into rational, it had to cope with some identitarian uncertainties from the beginning (Whooley 2019). Always on the boundary between human and natural sciences, psychiatry often comes back to the question of comparing quantitative and qualitative models to find the best tools to understand and explain humanity. The public debate about psychiatry has often been reduced to a rigid fight between "a romantic tradition, even irrationalist, hazily sentimental and [...] a classically rationalist and objectivist tradition" 
(Jervis 2007). This simplification does not allow us to understand the various factors (e.g. technical, social, cultural, political, psychological, humanitarian) that have always contributed to defining and redefining the moving boundaries between normal and pathological. ${ }^{1}$

During the 1960s, questions on the boundaries between reason and madness started receiving attention from society and politics like never before. Psychiatry, through best sellers and mass media, overcame the institutional and disciplinary boundaries and started affecting mass culture and everyday life. During 1968, psychiatry was shaken by antiauthoritarian protests and by radical critics of the diagnostic systems, as well as of institutional assistance and cure. The libertarian and antiinstitutional stances of some psychiatrists fascinated younger political movements, which absorbed them and elected such specialists as model intellectuals. A deep reflection, both cultural and political, was born at the time about mechanisms of social exclusion and the very idea of mental insanity. The walls of psychiatric hospitals were perceived as the concrete boundaries between reason and unreason. These had been built by society, which selected fools and expelled them through law. The Foucaultian ideas about the Big Internment (Foucault 1961) supported such a thesis, as did the arguments from the radical sociologists about deviance and total institutions (Goffman 1961; Becker 1963).

An analysis of the Italian case confirms the general dynamics described above but also presents some interesting peculiarities. In Italy, the protest movements started in 1968 extended way past the 1970s, and ended up affecting various disciplinary paths. Common ground was found not only within the workers' movement but also within politicized psychiatrists who were engaged in daily fights against the institutionalized system of asylums. The influence of feminist movements was particularly strong, with its interest in the relationship between private and public, between subjectivity and body, sharing with anti-psychiatry the search for new ethics. Finally, one of the most striking and well-known events of Italian history was the complete abolition of asylums. The Law 180/1978, which established such abolition, became the symbol (or the fetish) of an era as it was perceived as a historic turning point. Psychiatrist Franco Basaglia (along with his group) ${ }^{2}$ was considered the hero who "freed the fools from asylums" and is still considered one of the most influential antipsychiatrists in the West (Berlim, Fleck, and Shorter 2003). Actually, Law 180 wrongfully came to be known as the "Basaglia Law". This

\footnotetext{
${ }^{1}$ For an in-depth discussion of this topic, see Canguilhem (1966).

${ }^{2}$ For an intellectual and human biography of Basaglia, see Colucci and Di Vittorio (2001) and Pivetta (2012).
} 
representation has deeply conditioned historiography (Foot 2014, 2015; Burns 2019; Burns and Foot 2020), despite the efforts to go beyond such a simplification (Micheli 2019).

It is interesting, then, to analyse the debate on rationality, irrationality and irrationalism in a crucial phase such as the second half of the 1970s, woven together with anti-institutional psychiatry and the New Italian Left. This label denotes the movements and political groups started between the 1960s and the 1970s outside (and often in opposition to) traditional Leftwing parties. This was a period of crisis and new ideas during which "psy" disciplines became a tool or even a shelter for people who were disoriented by the end of 1968 movements. Such people were attracted by movements characterized by extremism, individualism, depoliticization and irrationalism (Donolo 1976; Jervis 1976a; Crainz 2003). In this scenario, psychological conflicts became political conflicts as well. Mental disturbances began to be interpreted - by a minority overall, but by a large group within the Left movements - not as a disorder or suffering caused by experience, but as the result of conventions and prejudices, or even as an expression of freedom and creativity that could help to overcome the bourgeois regime. Anti-psychiatry became a word that was used, abused, mythologized, misunderstood: the focus of an ideological battle about the boundaries between normality and madness. The general scenario was one of profound cultural and political transformation within the Left. Thus, the discussion about normality and madness was related to a more general one about rationality and irrationality within the crisis of reason.

\section{Other Perspectives and Definitions}

Madness also became a matter of perspective, to be considered either from the outside or the inside of the asylum walls. During the 1970s, as the idea of a definite separation between normality and madness had been set aside, psychiatrists working outside the institutions made it clear that the boundary between reason and unreason was not marked by the walls of the asylums. No longer confined within the hospitals, psychiatrists and mental health workers worked in the community where new problems and issues emerged, related to work, existential sadness, and other preoccupations. Moving to the cities and suburbs, they reached local health centres and community-based outpatient clinics, and they started to attend houses, schools and factories, often with the goal of prevention. Psychiatry was led back to its social matrix, where the relationship between sanity and malady 
had always been defined differently with respect to institutions. ${ }^{3}$ Even the fact that the patient was assessed by a multi-disciplinary team composed by psychiatrists, psychologists, social workers, and nurses, as stated by Law 431/1968, was a significant change. Similarly, the virtual impossibility to reside inside a psychiatric hospital, as expressed by the absence of beds, brought about major changes within Italian psychiatry. The opposition between a rational world outside and an irrational one inside did not work, and other means of interpretation and analysis were necessary.

Giovanni Jervis began working in the community coming from Gorizia's asylum which had been repudiated as a place of treatment by Franco Basaglia from $1961 .^{4}$ Jervis was in charge of the outpatient psychiatric services in the province of Reggio Emilia from 1969 to 1977. He was called to do so by the province administration, led by the Italian communist party at the time, in order to reform and democratize the assistance to psychiatric patients. Jervis had a solid social psychiatry background and had also been part of the team of Ernesto De Martino, the ethnologist and historian of religion who had chosen him to take part in the interdisciplinary research team on tarantism in Puglia at the end of the 1950s. ${ }^{5}$

Jervis published his Manuale critico di psichiatria in 1975 [Critical handbook of psychiatry]. The volume was reprinted several times, translated abroad and considered a landmark publication for various generations of psychiatrists and mental health workers. The last chapter was dedicated to a critique of normality analysed from a Marxist viewpoint, in light of needs and desires, class struggle, everyday life, subjectivity and "rationality of revolutionary conscience" (Jervis 1975a, 194-225). This way, Jervis was trying to give back to psychiatry more than just a new complicated vocabulary, but rather a historical, cultural and political background. However, he did not give up classifying and describing, as shown by the Piccolo dizionario ragionato di psichiatria

\footnotetext{
${ }^{3}$ Psychiatrists had been working in the community for over a hundred years, although not for anti-institutional purposes, as shown by the project realized under the scientific leadership of Patrizia Guarnieri, Fuori dal manicomio: Gli archivi della salute mentale dall'Unità d'Italia alla legge 180 (Outside the asylum: The archives of mental health from the Unity of Italy to Law 180),

https://siusa.archivi.beniculturali.it/cgi-bin/pagina.pl?RicProgetto=preg-tos-fuoman.

Accessed May 7, 2020.

${ }^{4}$ L'istituzione negata (The denied institution) is the title of a book, edited by Basaglia and ideated by Jervis, that described the experience within Gorizia's psychiatric hospital. It was published in 1968 by Einaudi and became a cult book for the students' movement that regarded the abolished psychiatric institution as a realized utopia (see Foot 2014, 131-152).

${ }^{5}$ For more details on Jervis and his work, see Marraffa (2014) and Fiorani (2016).
} 
[Little thoughtful dictionary of psychiatry], which was inserted as an appendix to his 1975 manual. The effort to redefine the boundaries between normality and madness during the 1970s was tightly connected to such a context: it concerned the institutional and community practices of a discipline (i.e. psychiatry) that sought a new identity. It was the object of a political and cultural discussion that was held not on specialized journals but mostly on the New Left venues, as the Left movements were beginning to reason about their crisis.

\section{The Crisis of Normality}

A special effort to treat such questions was made by the Quaderni Piacentini [Piacenza's Notebooks], a journal of dialogues and ideas from the New Left, open to discussing a variety of topics related to psychiatry and psychoanalysis. In the October of 1976 a double issue of the Quaderni was devoted to reflections on mythization and dogmatization. Sociologist Carlo Donolo opened the issue with a paper lucidly describing the transition taking place within the New Left. ${ }^{6}$ In his opinion, it was necessary to move beyond 1968 and its movements, with more objective and non-ideological analyses, in order to restore the ideal and intellectual heritage of the movement and to avoid the risk of being wiped out by a tide of de-politicization, individualism and irrationalism (Donolo 1976). Other contributions of the issue included the philosopher Franco Rella on the mythization of Freud; the Jungian analyst Silvia Montefoschi on the myth of feminism; and the militant feminist and psychoanalyst Manuela Fraire on the women's movement. A psychiatric point of view was needed in order to understand the cultural change within the Left and this was provided by Jervis with the essay Il mito dell'antipsichiatria [The myth of antipsychiatry], also part of the special issue.

The essay by Jervis (later translated also into French and German) joined a fierce discussion that included both scientific and political matters. Both the dominant image of normality and the role of psychiatrists were undergoing a crisis. In such a scenario, Jervis wrote that "anti-psychiatry" had become an abused expression, a source of lies and illusions. Within the more extreme Leftist groups, mental malady was discussed through a seductive jargon, thereby generating confusing and imprecise discourse. At the same time, references to Deleuze and Lacan, as well as to Foucauldian anti-authoritarianism, had become expressions of cultural fashion. Laing and Cooper were often cited, albeit wrongfully: in fact, the

\footnotetext{
${ }^{6}$ Donolo's essay has often been considered a perfect example of such a phase (see Crainz 2003, 542).
} 
former never acknowledged the term "anti-psychiatry" and the latter overtly stated that defining his position as anti-psychiatric was a misunderstanding (Jervis 1975a, 1976a, 1977a). Many ideas defined as anti-psychiatric were not novel: the quantitative relationship between normal and abnormal, sane and insane, had been already established by Freud, dynamic psychiatry, and interpersonal theories as opposed to being discovered by recent anti-psychiatric movements (Jervis 1976a).

This misunderstanding had practical as well as cultural effects, especially within psychiatric services, where some young militant clinicians were convinced that anti-authoritarianism on its own would solve the problem of mental health. On the other hand, people within the movement had adopted the "inconsistent and unusable" idea of madness as freedom, mistaking anti-authoritarian struggle for "typically bourgeois" permissiveness (Jervis 1976a, 47, 60). Such an ideological position, according to Jervis, puts the necessary affirmation of a different conception of normality and madness at risk. His view, rooted in Marxism and social psychiatry, does not necessarily regard biological damage as the origin of mental illness: rather, social and class contradictions would also feature as important causal factors. ${ }^{7}$ Extremism and the mythologization of antipsychiatric battles were, on the contrary, compatible with the most traditional positions of bourgeois rationality that they wanted to reject. ${ }^{8}$ In other words: "on the one hand, antipsychiatric tendencies and theories demonstrated the politic potential of a crisis; on the other hand, they managed to turn this very crisis into a bourgeois intellectual theory. Indeed, such tendencies and theories psychologized the disease instead of historicizing it; they labeled it through a formula and a series of deceptions. In the end they pretended to solve it through conservative, and even reactionary, methods" (Jervis 1976a, 40). Jervis had been warning against idealization, dogmatism and sectarianism in psychiatry for years (Jervis 1972, 36-37). Although he held a minority position, he was never alone (Guarnieri 2012). Others negatively considered the regressive simplification (from a cultural, operational, political point of view) originating at the beginning of the 1970s (Ajmone 1976; Gleiss 1976) as an attitude that was common within the protest movements but was also shared by humanist intellectuals and, even if not overtly, by some militant psychiatrists. $^{9}$

\footnotetext{
${ }^{7}$ To historically define psychiatry, Jervis cited — not by chance-authors such as Dörner (1969) and Ellenberger (1970).

${ }^{8}$ Cooper (1978) briefly responded by insisting on the relationship between madness and the need for autonomy.

${ }^{9}$ Most Italian psychiatrists, including Basaglia, rejected the notion of anti-psychiatry, and only used it as a synonym of anti-specialism (see Colucci and Di Vittorio 2001, 78). Jervis
} 
The crisis within the New Left was then tied to the very crisis of the concept of normality. It concerned the uncertainties of anti-institutional psychiatry and emerged within the organization called Psichiatria democratica [Democratic psychiatry], founded in 1973 by Basaglia, which tried to unify, without success, the various alternative psychiatric movements in Italy.

In this sense, it is worth noting that the attitudes that Jervis and others criticized were not representative of the whole complex anti-institutional environment in Italy. There were different places where outpatient psychiatry was successfully practiced, and it was also possible to discuss rationality and the crisis of reason with international experts and in scientific journals. ${ }^{10}$ Nevertheless, these experiences were tangential with respect to the debate within the New Left. Even people with similar ideas did not always manage to find a common ground for dialogue.

\section{Subjectivity, Normality, Madness}

In this phase, within the New Italian Left, and especially through feminist movements, special attention was dedicated to the reflection on personal needs and desires in connection with the public environment. More specifically, the relationship between subjectivity and collective movements, and between body and sexuality, was explored. Several themes were discussed, such as couple relationships, free and conscious reproductive rights, and sexuality. The ensuing battles also led to major transformations from a legal point of view, such as the Italian laws legalizing divorce and abortion.

In his Manuale, Jervis stated that "even everyday life is a political problem, because what is personal is political" (Jervis 1975a, 15). Criticizing the concept of normality, he regarded feminist groups as the only ones capable of developing and advancing a battle for a new conscience, one able to keep together new political urges: "a battle on the various fronts of everyday life" (Jervis 1975a, 213). Nevertheless, already in 1976, the theoretical references began to change and the efforts of "keeping together

came back to reflect on this period in a dialogue with medical historian Gilberto Corbellini in a book with the significant title La razionalità negata: psichiatria e antipsichiatria in Italia (Denied rationality: Psychiatry and Antipsychiatry in Italy; Corbellini and Jervis 2008).

10 The experience of Perugia was considered a positive example of outpatient psychiatric assistance and de-institutionalization (see Guarnieri 1997). Another successful example was Grosseto, where mental patients were assisted, like elsewhere in Italy, without having a mental hospital in the vicinity (see Fiorani 2012). 
Marxism and the individual through the theory of needs of Agnes Heller" remained separate (Jervis 1976c; see also Crainz 2012, 62). In this time, the interest in subjectivity and the political dimension of the personal became a tool to reflect on the loss of political sense and on the irrationalist drive. Also some Italian feminists started asking themselves:

if the feminist practice (meaning taking consciousness, to be clear, not the public manifestations) can start from subjectivity, without becoming subjectivism, or if we are flooding in a sea of irrationalism and intimism, whose ties with struggle, radical transformation, taking power are becoming weak. (Ravera and Usai 1976, 35)

In the newspaper la Repubblica (located in the reformist Left), journalist and writer Enzo Forcella wrote about the book Porci con le ali [Pigs with wings] — a bestseller that was reprinted many times and translated in many countries - as a sign of the crisis within the revolutionary Left (Forcella 1976). This book was written by Marco Lombardo Radice and Lidia Ravera and described the stories, both intimate and political, of Rocco and Antonia, two young high school activists. It was published by Savelli (a publisher close to the radical Left) and was the first of a series significantly called Il pane e le rose (Bread and roses), edited by the same Lombardo Radice and Ravera, together with Giaime Pintor and Annalisa Usai. The title referred, purposefully, to the English idiom "pigs have wings", quoted by David Cooper in The Death of the Family (Cooper 1971). A quote from Cooper's book appeared on the back cover of Porci con le ali. The authors, who were both active in the debate about subjectivity, love and sex, shared the ideas of a movement called Lotta Continua, which was broken up during the same year because of internal conflicts that feminism encouraged. This was interpreted as an emerging gender conflict, which was going to become more radical than the one between wage labour and capital.

While Porci con le ali was Ravera's first book which launched her career as a professional writer, Lombardo Radice was a 27 -year-old physician working as the chair of Psychophysiology at the University of Rome. He participated in the 1968 protests and, as a specialist, wrote with some colleagues in the newspaper l'Unità (the official voice of the communist party) to support the necessity of evaluating both social and biological aspects when assessing mental illness (Lombardo Radice, Venturini, and 
Ruggieri 1974). ${ }^{11}$ Afterwards, within the debate about social roles, he tried to introduce the idea of evaluating both the biological and psychological factors of behaviour (of men, women, heterosexuals, homosexuals, etc.): on his view, these factors went beyond the results of "social conditioning and learning". He expressed these ideas in an essay published in the activist journal Ombre Rosse (Lombardo Radice 1976b, 54). In the same year of Porci con le ali, Lombardo Radice also edited (together with Riccardo Venturini) the Italian edition of Le motivazioni biologiche (Biological motivations), written by the soviet physiologist Konstantin V. Sudakov. In the introduction he proposed a psychophysiological view of mental health within the debate about needs (Lombardo Radice and Venturini 1976). In the end, surely, Lombardo Radice could not be accused of naive wishful thinking. ${ }^{12}$ Porci con le ali was harshly criticized - albeit in a "friendly" way - in the same journal Ombre Rosse, as an individualistic and irrational product (Manconi and Sarno 1976).

\section{Rationality, Irrationality and Alternate Normality}

Following a path already started by feminist movements (Lonzi 1970), the New Left called into question the traditional meaning of rationality and the very connection between rationality and irrationality (Crainz 2012, 63). Irrationalism, started as an eminently cultural movement, became a political and ideological category. In this debate, the so-called drug ideology (which mostly concerned young people) played a central role and attracted militant psychiatrists and psychologists, especially with regard to the possibility of an alternative concept of normality.

In an essay from 1976 called Giovani senza rivoluzione [Young people without revolution], Lombardo Radice wrote about the connection between irrationality and irrationalism. He distinguished between the veterans of 1968 and the young people of the 1970s and, referring to the drug ideology, affirmed that the irrationalist ideas of a "deeply politicized and radically anti-bourgeois youth" could be important to "reappropriate a bond with nature, creativity, madness in a structurally and violently antibourgeois and revolutionary way" (Lombardo Radice 1976a, 21). Irrationalism, on the other hand, should be rejected because it denied the

\footnotetext{
11 The letter opened a discussion within the Marxist environment about the origin of mental illness (social or biological), which was gathered in a volume edited by two leading figures of the communist party: Berlinguer and Scarpa (1975).

${ }^{12}$ Lombardo Radice (1977) later wrote about institutionalized psychiatric violence within Lotta Continua, insisting on the paradox of the preposterous precision of diagnostic definitions and the sadism of psychiatrists. For a biography of Lombardo Radice, see Fiorani (2019).
} 
use of reason to interpret and change reality. Thus, the battle against the "irrationalist ideology" of psychotropic drugs was warranted in those cases where the 'trip' was perceived as the only means of knowledge (which was believed by very few people). However, the same battle was unwarranted if it wanted to restrict the search for an alternative rationality, which was not necessarily unreasonable. This way, Lombardo Radice was trying to save juvenile irrationalism, which could also be evaluated from a psychophysiological point of view, and which also represented a

drive to recover an important part of humanity, meaning a 'visceral brain', which, for an animal so highly corticalized as man, is somehow naturally submitted to the 'rational brain', but is today crushed and annihilated, for complex reasons, related to the evolution of history and society. (Lombardo Radice 1976a, 21; see his 1975)

Macondo, a former factory in Milan that had been transformed into a community space in the late 1970 s, with restaurants, discos, and rooms dedicated to music, reading, art exhibitions, and markets, was shut down in 1978 because of pervasive drug use. Mauro Rostagno, a leader of the Italian 1968 movements who had just left Lotta Continua, was among the founders of the space, ${ }^{13}$ which had been an effort to answer, in an alternative and creative way, to the crisis and disorientation of Leftist young people. In a way, it was a concrete experiment of new forms of normality. Indeed, changing the concept of normality appeared to be an ever more complicated enterprise, as it clearly emerges from the book devoted to the experience of Macondo (Rostagno and Castellacci 1978). Fiorello - member of the youth collective of Stadera, district of Milanpublished a critical review of the book in Ombre Rosse and highlighted that "gay people, feminists, freaks, addicts and so on" stayed away from gurus (such as David Cooper and André Glucksmann) who praised their liberation and participated in the same events. In this sense, the efforts to make them the "active subjects of transformation", to define their misery as "non-integration" had not worked out (Fiorello 1979, 165).

Jervis, in an article dedicated to drug ideology, described two essays by Rostagno and Romano Madera (another militant of the 1968 movement, later turned philosopher and Jungian analyst) as both mystifying and dangerous. These articles appeared in November 1975 in one of the most

\footnotetext{
${ }^{13}$ Rostagno's intellectual development was significant. After the closure of Macondo, he went to India, where he joined an Orange community in Poona. In 1981 he moved back to Italy and founded the Saman Community in Sicily, devoted to the recovery of drug addicts, based on a "pact among free men" and specific techniques inspired by Indian meditation. See Bigaran (2017) for more details.
} 
popular "counterculture" journals, Re nudo [Naked king, i.e. Emperor's New Clothes]. The praise of mental illness, the appreciation of psychotropic drugs such as LSD as a revolutionary path, and the appeal to a "non-rational liberation of the brain" that would replace political action, were all issues that, according to Jervis, the authors should be held responsible for. But the same responsibility applied to people who did not understand that "in the hand of the new post-1968 decadence, spontaneity had become improvisation, subjectivity had become subjectivism". In the end, Jervis wrote that it was "our fault too" if these questions did not receive appropriate answers (Jervis 1976b, 32-33).

On Jervis' view, mystical and esoteric temptations, hippie theories and fashions (which had arrived in Italy ten years later with respect to the United States), escape and self-destruction through drugs (ever more often heroine), a revaluation of madness as liberation and of marginality and deviance as revolutionary, irrationalist and regressive ideologies, should not be considered in terms of fighting the rational (class fight and organization) through the irrational (youth counterculture). This attitude, underscored also by Lombardo Radice (cited by Jervis, 1976b, 5, 29), did not meet the needs of young people: while adults were playing with their late 1968 subjectivism (thereby betraying the position that "the personal is political"), teenagers did not have a proper culture to refer to (Ibid., 33).

Despite the difference in age and experience, Jervis (born in 1933) and Lombardo Radice (together with others in the teams behind Ombre Rosse and Quaderni Piacentini) highlighted the contradictions of the movements but at the same time their potentialities, which should not be forgotten. This way, they both tried to address the needs of those young people, often students and mental health clinicians and workers, who were sincerely interested in discussing and understanding the crisis of normality and reason in all its cultural, scientific, and political aspects.

\section{Irrationalism and the Crisis of Reason}

The explosion of the so-called 1977 movements (which lasted almost a year and had Rome, Milan, and Bologna as their epicenters), along with their irony and ferocity towards their 1968 predecessors, contributed to the search for new behaviours and politics in order to radicalize the fight between reason and un-reason, as well as between rationalism and irrationalism.

Together with the classical texts of the earlier culture-The Death of Family by Cooper (1971); The Divided Self and The Politics of Experience 
by Laing $(1960,1967)$ — it is a shared opinion that 1977 brought to the fore new reference books. One of them was the Anti-Oedipus by Deleuze and Guattari. By contrast, Foucault was not only regarded as the theoretician of the big institutional internment of madness, but also as the one who first highlighted the molecular power of human relationships. ${ }^{14}$

A critical piece about the popularity of the so-called nouveaux philosophes was published in Ombre Rosse by Luigi Manconi, Gad Lerner and Marino Sinibaldi, who were both customary collaborators of the journal and wellknown members of Lotta Continua. Their essay rejects the standard representation, usually endorsed by the "bourgeois press", of the movement as culturally homogeneous and uniformly seeking meaning through irrationalistic categories (Lerner, Manconi, and Sinibaldi 1977). "Microphysics of power", "desiring flow" and "desiring machines" were concepts that were not very well-known in Italy at the time-who had actually read the Anti-Oedipus? (Deleuze and Guattari 1972) Manconi, Lerner and Sinibaldi wondered - and as a consequence not very clear to most people. On the other hand, reason and unreason, rationality and irrationality, kept being concepts to be reasoned and discussed about within the New Left. A 1977 photograph by Tano D'Amico portrayed a girl lying down, with a book on her chest entitled Donne, povere matte: inchiesta nell'Ospedale psichiatrico di Roma [Women, poor fools: Inquiry into the psychiatric hospital of Rome] ${ }^{15}$ exemplifies another crucial issue, namely the relationship between feminism and antipsychiatry.

Both criticizing authoritarianism and the political culture of the Left, antipsychiatry and feminism shared the goal of tracking subjective and intersubjective paths, which were alternative to the process of homologation through normality. As Marthe Van De Meulebroeke wrote in 1976 in the feminist journal Effe: "What Laing accepted to call antipsychiatry could become the whole psychiatry; it could come out of psychiatry and change our everyday relationships with others", (Van De Meulebroeke 1976). More cautious were the comments to the symposium Donna e follia [Woman and madness] held in Florence on November 12, 1977 and published in the same journal the following year. In this issue they highlighted the contradiction between the mythization of the fool, who joined the way of madness as a "conscient political choice against the

\footnotetext{
${ }^{14}$ Microfisica del potere (Microphysics of Power) was published in Italy in 1977 (Foucault 1977).

${ }^{15}$ For the book, see Harrison (1976). The photograph has been published in a special issue of Robinson, a journal periodically attached to the newspaper la Repubblica, whose title was "Settantasette. Parole e immagini" [Seventyseven. Words and images], issued February 12,2017 ,

https://www.repubblica.it/static/robinson/numero-11/settantasette/, accessed May 1, 2020.
} 
imposed norm", and the negative definition of fools, applied to women who broke the rules of a male chauvinist society (see Tagliaferri 1977; Vitas 1977; Vitas et al. 1977).

In 1977 the philosophy journal Aut Aut-which had been discussing the theme of needs during the 1970s-decided to dedicate an issue on Irrazionalismo e nuove forme di razionalità [Irrationalism and new forms of rationality], given the "political hardening" and the ideological struggle around these questions. Intellectuals from different backgrounds and experiences were called up to express their opinion. Among them was Giovanni Jervis, who considered the conflict about rational and irrational to be in the heads and behaviour of people.

From as far back as Freud and Jung, who had well demonstrated the links between rational and irrational, Jervis stated that in the "human psychic structure" reason and unreason have always lived together. Psychology, psychoanalysis, and Marxism had already shown that "personality and the human psyche cannot be divided into a socio-rational and a naturalinstinctual part" (Jervis 1977b, 41). Jervis later referred to Herbert Marcuse's work (1955), and in particular to the illusion, based on a "metahistorical naturalism", of considering certain behaviours (e.g. imagination, eversion, spontaneous, madness) as liberatory. By contrast, in his opinion they were functional to the system, because

romantic models, literary avantgardes, decadent forms of irrationalism, ideologies of instincts, violence, immediacy, irreflexivity, partying and totalization [...] might deceive pleasure and desire and end up leading them to authoritarian grounds, where the abuse becomes law. (Jervis 1977b, 41)

Irrationalism was then not only unhelpful to overcome capitalistic rationality, but it actually ended up reinforcing the stability of the capitalist system. Indeed, if irrationality

is just another face of bourgeois reason, irrationalism also shares its structure: it favors the same interest of the system toward stability, or even more authoritarian forms of social control. (Jervis 1977b, 43)

The essay ended quite bitterly, with a sort of personal and collective assessment: The New Left had been unable to clarify the themes of rationality and irrationality. In opposition to the "rational bourgeois" positions of the communist party, the only answers had been desperately irrational attitudes. 
In the same issue, feminist Lea Melandri harshly criticized Jervis for his position on needs (which she considered as old-fashioned Marxist) and his criticism of the mythization of anti-psychiatry and drugs. The main problem was in the conception of the connections between normality, madness and irrationalism. The cautious attitude of Jervis, Melandri wrote, more than the effort of saving

normality and madness, feast and necessity, individual and history, leaks out censorship, dogmatic rigidity, Manichaean moralism, which distinguishes between, on the one hand, the sane reason [...], on the other, 'irrationalism', 'drift', 'regression', 'disorder', 'instinctivism', 'bad faith'. (Melandri 1977)

The needs of life that have been extensively discussed had transformed classical rationality into something brittle and precarious. "The ways of thinking could be several and reason was in crisis" wrote philosopher Aldo Gargani when introducing the 1979 volume La crisi della ragione (The crisis of reason) - a collection of interdisciplinary essays (Gargani 1979). By criticizing classical notions of reason, Gargani tried to deepen the debate on rationalism and irrationalism in order to escape from ideological positions. His answer gave relief to militants, younger and older, who were uncomfortable with the denial of social roles and professional competence and with anti-psychiatric generalizations. It worked well as a manifesto for those who were not searching for expedients but rather for new ideals of rationality and political paths. ${ }^{16}$ Against extreme irrationalist positions, these people appreciated discussions of classical reasons, such as those collected by Gargani and also internationally by Kuhn and Feyerabend. In these works, science was criticized without being devalued - as had always been done by Italian neo-idealistic thought. Similarly, new models of rationality, less univocal and more complex than the ones offered by the Galilean tradition, were embraced. ${ }^{17}$ In satisfying this need for knowledge, an important role was played by Left-leaning publishers (such as Feltrinelli, Einaudi, and others), who translated works especially from the USA.

\footnotetext{
${ }^{16}$ Historian Patrizia Guarnieri wrote about the reasons why, as a "student or little more", it was comforting for her to read Jervis, with respect to the simplifications and equivocations of certain anti-psychiatry during the second half of the 1970s (Guarnieri 2012, 69). It is interesting also to highlight the unexpected re-reading of Nietzsche by young people, stated by historian Guido Crainz, in order to overcome the "old categories of rationality" and the search for "new behaviors and new politics" (Crainz 2012, 63).

17 This is what Guarnieri notes in a testimony about these years (personal communication). I thank Patrizia Guarnieri for the testimony and for her observations on this contribution.
} 


\section{A Cul de Sac?}

Despite the anxious quest for answers, at the end of the 1970s Italian activists appeared to be in a cul de sac. Even Marxism (in all its variations) seemed unable to satisfy the collective and individual need for knowledge. Despite extensive discussions, even the ideas about normality and madness were still not well-defined, as it clearly emerges from the journals of the movement during these years. Here, harsh judgements prevailed over the efforts to recover the positive aspects of the battle against mental institutions and the critics of normality.

The "systematic praise of madness", as Alfonso Belardinelli and Giovanni La Guardia noted in Quaderni Piacentini, was the symbol of how the New Left was getting old. Such a psychiatric reversal was not even useful in integrating the dropouts, as noted by Roberto Polce of the Gay Collectives from Milan (formerly Nostra signora dei fiori) in the journal Ombre Rosse. In this essay, Polce compares the contradictions of the path towards the liberations of gay people and mad people who came out from the institutions just to be marginalized again from society (Polce 1978). First embraced as a "conceptual subversive model of schizophrenia and mental illness", through abstract representations of suffering, the conception of pathology as "areas which were independent from the normalization power" was not useful to understand the real bites of illness, as Mirella Serri wrote also in Ombre Rosse the same year (Serri 1978). Reacting against the inhumanity of psychiatric institutions had been rightful, noted Alberto Mellucci in the Quaderni Piacentini, but it failed to provide answers to the basic questions: what is madness, how to interpret it within society along the new praxis and how to use one's body and identity (Mellucci 1978).

At the end of the 1970s, difficulties and anxiety seem to characterize Italian anti-institutional psychiatry in an even more evident way. This climate can be perceived by looking at the third meeting of the Réseau internazionale di alternativa alla psichiatria [International Network of Alternatives to Psychiatry], entitled Il circuito del controllo [The circuit of control], which was held in September 1977 at the psychiatric hospital of Trieste. This venue was highly symbolic because it had been directed since 1971 by Franco Basaglia, who was soon going to announce its closure before the Law 180/1978 would close all Italian mental institutions. There were 4,000 participants (among them Cooper and Guatari): not only psychiatrists and mental health clinicians and workers, but also young people and collectives (both Italian and French). There was a crescendo of tension and antipsychiatric slogans. During one turmoils, Basaglia broke a rib. Nonetheless, he declared that he wanted dialogue at all costs because 
"beyond sanity, the life of oppressed people matters" (Giliberto 1977). What one of the collectives declared to the press seemed significant to understand the ongoing confusion among social roles:

Yesterday we shouted that we wanted Basaglia as principal of the Asinara prison. No one understood that it was not an insult but a hope. Many comrades that are closed in that concentration camp would like to have a person like Basaglia in charge: as a first thing, he would keep away the bars from the windows and open the doors, as he did in the mental hospital of Trieste. (Giliberto 1977)

Another article written by Enzo Siciliano, a writer and literary critic, entitled La psichiatria democratica in cerca di senso [Democratic psychiatry in search for meaning], in 1978 describes the situation as follows. Between Laing and Cooper, Guattari and Foucault, Basaglia's "romanticism" and Jervis' "rationalism", illness and norm, institution and community, the direction seemed uncertain. Despite the results achieved, Siciliano noted that many radical questions posed during the previous ten years were still unanswered. Can anti-psychiatry help the insane? Can drugs? Can psychoanalysis? Is an individual good even if s/he exhibits deviance? Article was written just before the reform that would have closed mental institutions at the end of the so-called season of movements. Reflecting on a decade of militant psychiatry, and on the connections between madness and politics, this seemed to be ever more urgent and necessary.

Jervis followed up on this issue by giving voice to his own subjectivity, through an individual and collective biography from 1951 to 1976 that prefaced a selection of published and unpublished works (Jervis 1977c). Basaglia himself tried to sum up his experience in the volume La nave che affonda [The Sinking ship] from 1978, which consisted in the transcripts of heated discussions held in his Venice house with his wife Franca Ongaro, Agostino Pirella (from the Gorizia team and director of the Arezzo psychiatric hospital at the time), and journalist Salvatore Taverna. The sinking ship was symbolizing the mental institution: the focus of discussions and the core issue of future psychiatry. On the same wavelength, in 1979, Basaglia and Ongaro Basaglia tried to define, in extremis, the entries "madness" and "delusion" for the Einaudi Encyclopedia (Basaglia and Ongaro Basaglia 1979).

Two years after the approval of Law 180/1978, the sociologist Ota De Leonardis, while reflecting on the concept of deviance, affirmed that the battle against mental institutions did not achieve the goal of re-defining the 
relationship between normal and pathological, as various problems emerged in the process of de-institutionalizing and re-socializing mentally ill people. The very same pretense of giving voice to madmen and, through them, to the revolutionary conscience had been re-absorbed within the administrative management of mental illness after the law became effective. Marginalized deviant people, bringers of the un-reason, had been reinstated into the subordinate role of the consumer (De Leonardis 1980). Despite the closed hospitals and the variety of alternative outpatient psychiatric experiences, there was still a felt necessity to reckon with a recent but cumbersome past as well as with the efforts of giving madness the role of a new form of rationality, in opposition to a society that was considered a mass institution itself. ${ }^{18}$ In such a scenario of political and social crisis, the individual had become an abstraction, only capable of saving the innocence of un-reason in an intimist and irrationalist regression.

The psychiatric questions - such as the definitions of normal and pathological - following the de-institutionalization process, should be (by law) brought into the community to find a new theoretical and practical sense. The dissatisfaction of many, both from the New Left and antiinstitutional psychiatric movements in Italy, ${ }^{19}$ was well-expressed by Carlo Manuali, head of the outpatient psychiatric services of Perugia. Manuali was concerned with the incapacity to think about psychiatry outside the institution, given the everyday difficulties brought up in the context of where people lived. Mental illness was, as he wrote in 1980, "a biographic event, and biographic needs have a more rapid rhythm than the social development on the whole" (Manuali 1980). ${ }^{20}$ There was still a long road ahead, also beyond political movements, given the "return of naturalism" bursting out around the early 1980s.

\section{Acknowledgments}

I thank Marco Innamorati for the help.

\footnotetext{
${ }^{18}$ See Basaglia and Ongaro Basaglia $(1971,1975)$.

${ }^{19}$ Such a dishomogeneity clearly emerges in the effort of De Salvia and Crepet (1982) to track "a critical epidemiology of the reformation".

${ }^{20}$ See also Manuali et al. (1978) on how psychiatry was no longer only struggling with institutional marginalization, but also with social factors of illness.
} 


\section{REFERENCES}

Ajmone, T. 1976. Partecipazione e politica del territorio. Inchiesta 22: 314.

Basaglia, F., and F. Ongaro Basaglia. 1971. La Maggioranza Deviante. L'Ideologia del Controllo Sociale Totale. Turin: Einaudi.

Basaglia, F., and F. Ongaro Basaglia. 1975. Crimini di Pace. Ricerche sugli Intellettuali e sui Tecnici come Addetti all'Oppressione. Turin: Einaudi.

Basaglia, F., and F. Ongaro Basaglia. 1979. Follia/delirio. In Enciclopedia Einaudi, vol. VI, 262-287. Turin: Einaudi.

Becker, H. S. 1963. Outsiders. Studies in the Sociology of Deviance. New York: Free Press of Glencoe.

Belardinelli, A., and G. La Guardia. 1978. Restaurazione e liberazione. Osservazioni sull'invecchiamento della nuova sinistra. Quaderni Piacentini 69: 11-17.

Berlim, M. T., M. P. Fleck, and E. Shorter. 2003. Notes on antipsychiatry. European Archives of Psychiatry and Clinical Neuroscience 253: 61-67.

Berlinguer, G., and S. Scarpa, eds. 1975. Psichiatria e Società. Rome: Editori riuniti.

Bigaran, M. P. 2017. Rostagno Mauro. In Dizionario biografico degli Italiani, vol. 88. Roma: Istituto della Enciclopedia Italiana. http://www.treccani.it/enciclopedia/maurorostagno_\%28Dizionario-Biografico\%29/. Accessed April 26, 2020.

Burns, T. 2019. Franco Basaglia: A revolutionary reformer ignored in Anglophone psychiatry. Lancet Psychiatry 6(1):19-21.

Burns, T., and J. Foot, eds. 2020. Basaglia's International Legacy: From Asylum to Community. Oxford: Oxford University Press.

Canguilhem, G. 1966. Le Normal et le Pathologique. Paris: Presses Universitaires de France; Italian translation, Turin: Einaudi, 1998.

Colucci, M., and Di Vittorio, P. 2001. Franco Basaglia. Milan: B. Mondadori.

Cooper, D. 1971. The Death of the Family. London: Penguin; Italian translation, Turin: Einaudi, 1972.

Cooper, D. 1978. L'antipsichiatria demitologizzata. Risposta a Giovanni Jervis. Aut Aut 165/166: 200-2004.

Corbellini, G., and G. Jervis. 2008. La Razionalità Negata. Psichiatria e Antipsichiatria in Italia. Turin: Bollati Boringhieri.

Crainz, G. 2003. Il Paese Mancato. Dal Miracolo Economico agli Anni Ottanta. Rome: Donzelli. 
Crainz, G. 2012. Il Paese Reale. Dall'Assassinio di Moro all'Italia di Oggi. Rome: Donzelli.

De Leonardis, O. 1980. Devianza: crisi e critica. Quaderni Piacentini 74: 71-83.

De Salvia, D., and P. Crepet, eds. 1982. Psichiatria senza Manicomio. Milan: Feltrinelli.

Deleuze, G., and F. Guattari. 1972. L'Anti-Oedipe. Capitalisme et Schizophrénie. Paris: Deninuit; Italian translation, Turin: Einaudi, 1975.

Donolo, C. 1976. Oltre il '68. La società italiana tra mutamento e transizione. Quaderni Piacentini 60/61: 3-38.

Dörner, K. 1969. Bürger und Irre. Zur Sozialgeschichte und Wissenschaftssoziologie der Psychiatrie. Frankfurt: Europäische Verlagsanstalt; Italian translation, Rome-Bari: Laterza, 1975.

Ellenberger, H. F. 1970. The Discovery of the Unconscious. The History and Evolution of Dynamic Psychiatry. New York: Basic Books; Italian translation, Turin: Bollati Boringhieri, 1972.

Fiorello, 1979. Macondo. Ombre Rosse 27/28: 164-165.

Fiorani, M. 2012. Follia senza Manicomio. Assistenza e Cura ai Malati di Mente nell'Italia del Secondo Novecento. Naples: Edizioni Scientifiche Italiane.

Fiorani, M. 2016. Jervis Giovanni. In Dizionario biografico degli italiani.

Roma: Istituto della Enciclopedia Italiana,

http://www.treccani.it/enciclopedia/giovanni-

jervis_\%28Dizionario-Biografico\%29/.Accessed May 15, 2020.

Fiorani, M. 2019. Lombardo Radice Marco. In Dizionario biografico degli italiani. Roma: Istituto della Enciclopedia Italiana,

http://www.treccani.it/enciclopedia/marco-lombardoradice_\%28Dizionario-Biografico\%29/. Accessed May 20, 2020.

Foot, J. 2014. La "Repubblica di matti". Franco Basaglia e la Psichiatria Radicale in Italia, 1961-1978. Milan: Feltrinelli.

Foot, J. 2015. The Man who Closed the Asylums. Franco Basaglia and the Revolution in Mental Health Care. London: Verso.

Forcella, E. 1976. "Porci con le ali": perché il sequestro? la Repubblica, December 8.

Foucault, M. 1961. Histoire de la Folie à l'Âge Classique. Paris: Plon; Italian translation, Milan: Bompiani, 1963.

Foucault, M. 1977. Microfisica del Potere. Turin: Einaudi.

Gargani, A. ed. 1979. La Crisi della Ragione. Turin: Einaudi.

Giliberto, F. 1977. Trieste: un convegno "modello di follia"? La Stampa, September 16.

Gleiss, I. 1976. Il contenuto conservatore dell'antipsichiatria. Psicoterapia e Scienze Umane 3: 6-15. 
Goffman, E. 1961. Asylums. Essays on the Social Situation of Mental Patients and Other Inmates. Garden City, NY: Doubleday; Italian translation, Turin: Einaudi, 1968; introduction by $\mathrm{F}$. Basaglia and F. Ongaro Basaglia.

Guarnieri, P. 1998. Per una storia della psichiatria anti-istituzionale. L'esperienza del rinnovamento psichiatrico in Umbria 19651995. Annali di Neurologia e Psichiatria 2 (Suppl.): 5-63.

Guarnieri, P. 2012. Presente e passato. L'interesse di Jervis per la storia. Medicina nei Secoli 1: 55-78.

Harrison, L. 1976. Donne, Povere Matte. Inchiesta nell'Ospedale Psichiatrico di Roma. Rome: Edizioni delle Donne.

Jervis, G. 1972, Manicomi eccetera. Inchiesta 5: 33-37.

Jervis, G. 1975. Manuale Critico di Psichiatria. Milan: Feltrinelli.

Jervis, G. 1976a. Il mito dell'antipsichiatria. Quaderni Piacentini 60/61: 39-60.

Jervis, G. 1976b. L’ideologia della droga. Quaderni Piacentini 58/59: 332.

Jervis, G. 1976c. Quali bisogni. Alcune note. Ombre Rosse 17: 5-11.

Jervis, G. 1977a. Non sparate al terapeuta. Quaderni Piacentini 62/63: 192-193.

Jervis, G. 1977b. Un parere su razionalità, irrazionalità e irrazionalismo. Aut Aut 161: 39-44.

Jervis, G. 1977c. Il buon rieducatore. In Id. Il buon rieducatore. Scritti sugli usi della psichiatria e della psicoanalisi, 9-42. Milan: Feltrinelli.

Jervis, G. 2007. Complessità e ricerca in cinquant'anni di psichiatria in Italia. Epidemiologia e Psichiatria Sociale 2: 139-143.

Laing, R. D. 1960. The Divided Self. A Study of Sanity and Madness. London: Tavistock Publications. Italian translation, Turin: Einaudi, 1969; preface by L. Jervis Comba.

Laing, R. D. 1967. The Politics of Experience. New York: Pantheon books. Italian translation, Milan: Feltrinelli, 1968.

Lerner, G., L. Manconi, and M. Sinibaldi. 1977. Le altre stagioni del movimento di primavera. Ombre Rosse 22/23: 3-39.

Lombardo Radice, M. 1975. I giovani e la droga. Ombre Rosse 9/10: 5666.

Lombardo Radice, M. 1976a. Giovani senza rivoluzione. Ombre Rosse 15/16: 9-23.

Lombardo Radice, M. 1976b. Tre domande nel dibattito sulla famiglia. Ombre Rosse 14: 53-56.

Lombardo Radice, M. 1977. L'ultimo paziente dello psichiatra Coda. Lotta Continua, December 6.

Lombardo Radice, M., R. Venturini, and V. Ruggieri. 1974. Psichiatria ed emarginazione sociale. l'Unità, July 18. 
Lombardo Radice, M. and R. Venturini. 1976. Preface. In K. V. Sudakov, Le Motivazioni Biologiche, V-IX. Florence: Giunti-Barbera.

Lonzi, C. 1970. Sputiamo su Hegel. Rome: Editoriale Grafica.

Manconi, L. and M. Sarno. 1976. Porci (?) con le ali (?). Ombre Rosse 17: 58-62.

Manuali, C. 1980. Without title. In Dove Va la Psichiatria? Pareri a Confronto su Salute Mentale e Manicomi in Italia dopo la Nuova Legge, eds. L. Onnis and G. Lo Russo, 98-150. Milan: Feltrinelli. Manuali, C. et al. 1978. Ipotesi sulla malattia mentale e criteri di operatività sul territorio. Fogli di informazione 50: 336-340.

Marcuse, H. 1955. Eros and Civilization. A Philosophical Inquiry into Freud. Boston: Beacon Press; Italian translation, Turin: Einaudi, 1964; introduction by G. Jervis.

Marraffa, M. 2014. Giovanni Jervis: la ricerca della concretezza. In G. Jervis, Contro il sentito dire. Psicoanalisi, psichiatria e politica, ed. M. Marraffa, XIII-XCIV. Turin: Bollati Boringhieri.

Melandri, L. 1977. Ascetismo rosso. Aut Aut 161: 58-66.

Mellucci, A. 1978. Dieci ipotesi per l'analisi dei nuovi movimenti. Quaderni Piacentini 65/66: 3-19.

Micheli, G. A. 2019. Not just a one-man revolution: The multifaceted antiasylum watershed in Italy. History of Psychiatry 30(2): 133-149.

Pivetta, O. 2012. Franco Basaglia, il Dottore dei Matti. La Biografia. Milan: Dalai.

Polce, R. 1978. Il vizio dello struzzo (ovvero: c'è uomo e uomo). Ombre Rosse 24: 86-94.

Ravera, L., and A. Usai. 1976. I tempi delle donne sono i tempi che le donne si danno. Ombre Rosse 15/16: 30-38.

Rostagno, M., and C. Castellacci. 1978. Macondo. Milan: SugarCo.

Serri, M. 1978. Fratelli. Ombre Rosse 26: 102-103.

Tagliaferri, M. 1977. Dalla follia alla liberazione. Effe 12: http://efferivistafemminista.it/2014/11/dalla-follia-allaliberazione/, Accessed, May 20, 2020.

Van De Meulebroeke, M. 1976. La religione e la donna. Effe 2: 12-15.

Villa, A. 1979. Tra il cane e il lupo. Ombre Rosse 27/28: 110-118.

Vitas, E. 1977. Le così dette pazze. Effe 10:

http://efferivistafemminista.it/2014/11/le-cosi-dette-pazze/, Accessed May 20, 2020.

Vitas, E. et al. 1977. Testimonianze. Effe 12:

http://efferivistafemminista.it/2014/11/testimonianze-3/,

Accessed May 20, 2020.

Whooley, O. 2019. On the Heels of Ignorance. Psychiatry and the Politics of Not Knowing. Chicago: University of Chicago Press. 
Matteo Fiorani

122 